\title{
Evaluation of Shear Bond Strength of Composite to Porcelain According to Surface Treatment
}

\author{
Claudia Minami KUSSANO \\ Gerson BONFANTE \\ José Gilmar BATISTA \\ João Henrique Nogueira PINTO \\ Prosthodontics Department, Hospital for Rehabilitation of Craniofacial Anomalies, University of São Paulo, \\ Bauru, SP, Brazil
}

\begin{abstract}
This study evaluated the shear bond strength of porcelain/composite using 40 metal + porcelain + composite cylindrical specimens divided into 4 groups, according to porcelain surface treatment: 1) no treatment, 2) mechanical retentions performed with diamond burs, 3) etching with phosphoric acid+silane, and 4) etching with hydrofluoric acid+silane. After being stored in distilled water at room temperature for one week, the specimens were submitted to a shear force (load) and the data were analyzed statistically (ANOVA). The means (in Mpa) of the groups were: 4.71 (group 1); 4.81 (group 2); 11.76 (group 3); 11.07 (group 4). There were no statistically significant differences between groups 1 and 2 and between groups 3 and 4 .
\end{abstract}

Key Words: porcelain/composite bond strength, repair, porcelain surface etching.

\section{INTRODUCTION}

Metal-ceramic crowns are a restorative treatment alternative which combines metal resistance and porcelain esthetics, tending to last for many years if made according to specific technical rules. Factors such as impact and fatigue, occlusal forces, and incompatibility between metal and porcelain physical properties may result in porcelain fracture, frequently of a cohesive nature (1-3). Due to the inherently brittle nature of ceramic restorative materials, failure under intraoral conditions of metal-ceramic restorations is not uncommon (4). The majority (65\%) of the failures have been observed in the anterior region, whereas $35 \%$ were in the posterior region. Sixty percent of the failures occurred at the labial, $27 \%$ at the buccal, $5 \%$ at the incisal, and $8 \%$ at the occlusal regions. These fractures were mainly in the maxilla (75\%), predominantly at the labial surface (5). Thus, it is necessary to assess the possible causes of fracture, so that the most suitable treatment can be recommended. Depending on the extension of the area to be restored, cost and time available may range from the making of a new prosthe- sis, facet (6), overcasting (7) to a composite repair (8$10)$.

According to Kato et al. (11), the bond strength to porcelain was predominantly influenced by the type of conditioning agent rather than the type of luting agent.

Usually, when performing repair with composite on porcelain, the surface must be prepared with burs, sandblasted with aluminum oxide, etched and silaned. The increase in porcelain surface roughness by means of diamond burs and discs contributes to the repair's adhesive resistance, and the use of acids, by creating microretentions, improves adhesion, producing cohesive failures if used with silane agents (12). Research shows that sandblasting with $50-\mu \mathrm{m}$ aluminum oxide is a better method for preparing the surface than bur performed retentions (13). Nevertheless, sole sandblasting is not sufficient to improve the bond of composite-porcelain interface $(4,14)$.

In one of the first studies on porcelain repair with composite, utilizing a silane agent, it was verified that this technique might be a clinical solution to fractured 
porcelain repairs (15). Silanization improved repair resistance when hydrofluoric acid was previously utilized (16). However, there is no consensus on the best porcelain treatment method to be applied in different clinical situations.

Thus, aiming at further clarifying this issue, the present study evaluated the porcelain-composite bond strength, employing several methods for surface treatment associated with an adhesive system prior to resin application.

\section{MATERIAL AND METHODS}

Forty metal + porcelain + composite specimens were made using a stainless steel matrix, comprised of

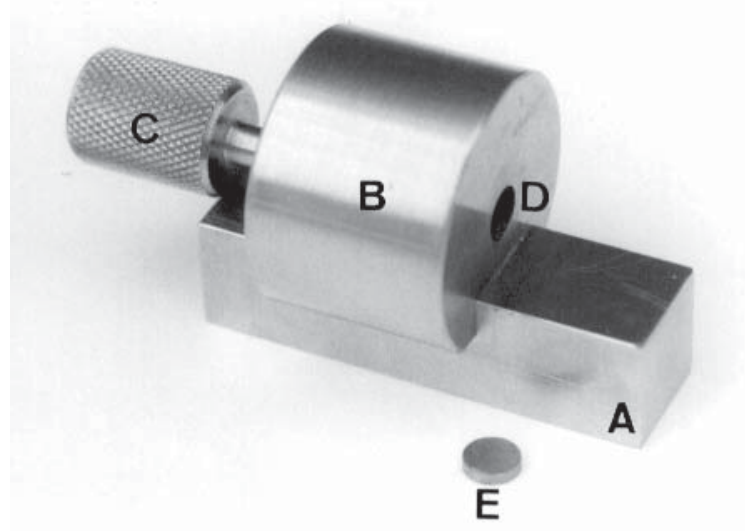

Figure 1. Stainless steel matrix used for making the specimens. A) Base. B) Cylinder. C) Screw. D) Frontal perforation. E) Spacing disc.

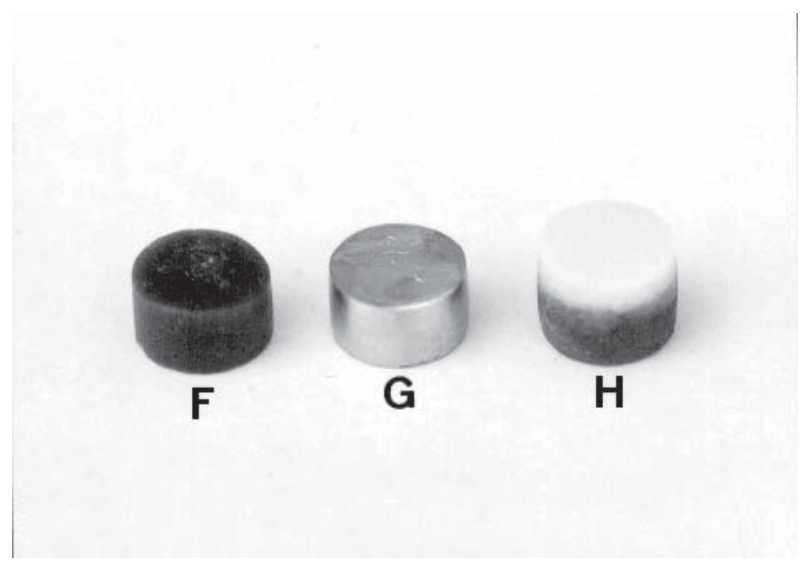

Figure 2. Manufacturing phase. F) Wax pattern. G) Cast pattern. H) Metal + porcelain. a metallic base over which a 22.0-mm high X 30-mm diameter cylinder was adapted, presenting a central perforation of $6.5-\mathrm{mm}$ deep by $6.0-\mathrm{mm}$ diameter surface, determining specimen dimensions. The opposite surface had a 5.0-mm diameter screw, utilized for specimen removal following condensation and stabilization of the set during shear tests. The matrix had spacing discs of $6.0 \mathrm{~mm}$ diameter by $1.5 \mathrm{~mm}$ height, which adapted to the central perforation, allowing thickness standardization of the metal ( 2 discs; $3.0 \mathrm{~mm}$ height X $6.0 \mathrm{~mm}$ diameter), porcelain (1 disc; $1.5 \mathrm{~mm}$ height X $6.0 \mathrm{~mm}$ diameter) and composite (no disc; 1.5 $\mathrm{mm}$ height $\mathrm{X} 6.0 \mathrm{~mm}$ diameter). The matrix and spacing disc are shown in Figure 1.

To obtain the wax pattern, 2 discs were positioned in the interior of the matrix, corresponding to porcelain and composite portions. Fused wax was poured and, after cooling, removed with the aid of the screw. The patterns were cast in Ni-Cr alloy (Durabond Universal, São Paulo, SP, Brazil) and polished with aluminum oxide abrasive burs at low rotation until their complete fitting in the interior of the matrix. One of the surfaces was sandblasted with $50-\mu \mathrm{m}$ aluminum oxide particles (Trijato Odonto Larcon, Maringá, PR, Brazil), after which the metallic discs were cleaned and degreased in pressurized water steam (Vaporeto, Polti, Italy), for $1 \mathrm{~min}$. After drying, these surfaces were kept free from manual contact. Conventional application and opaque firing in paste, in two layers (Opaquer, IPS Classic, Ivoclar), and specimen porcelain was done according to manufacturer instructions. Figure 2 shows the manufacturing phase.

The ceramic surface was made uniform by abra-

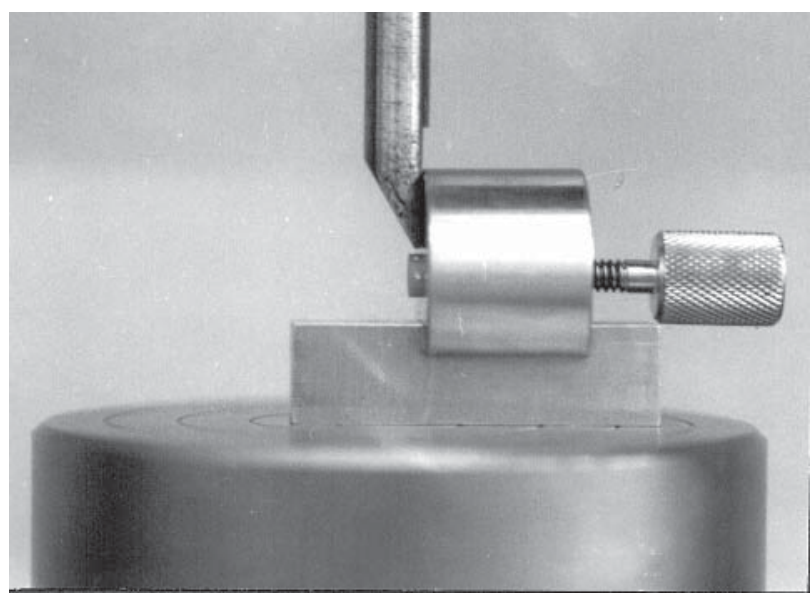

Figure 3. Matrix with the specimen in place for test execution. 
sion with a $2214 \mathrm{KG}$ Sorensen diamond bur prior to surface treatment. The specimens were randomly divided into 4 groups of 10 specimens each. Group 1: Control. Application of one layer of adhesive (Scotchbond Mult Purpose Plus, 3M, Sumaré, SP, Brazil), light-cured for $20 \mathrm{~s}$, and insertion of composite in small portions (Z100, 3M), light-cured for $40 \mathrm{~s}$, according to manufacturer instructions. Group 2: Preparation of mechanical retentions with a wheel-shaped diamond bur (KG Sorensen 1052, Barueri, SP, Brazil), adhesive application, light curing for $20 \mathrm{~s}$, insertion of composite and light curing for $40 \mathrm{~s}$. Group 3: Application of 35\% phosphoric acid gel (Scotchbond Mult Purpose Plus, $3 \mathrm{M}$ ) over porcelain surface for $1 \mathrm{~min}$, washing and drying, application of silane agent in 2 layers (Ceramic Primer, Scotchbond Mult Purpose Plus, 3M), allowing drying. The procedure to apply the bond and resin agent was similar to that in the previous group. Group 4: The only difference between this group and group 3 was the application of $10 \%$ hydrofluoric acid gel (Dentsply, Rio de Janeiro, Brazil) for $4 \mathrm{~min}$, in lieu of phosphoric acid.

The specimens were subsequently stored in distilled water, at room temperature, for 7 days, and then submitted to shear tests in a universal assay machine (Kratos, Dinamômetros Kratos Ltda, São Paulo, SP, Brazil) with a $0.5-\mathrm{mm} / \mathrm{min}$ speed. The active tip was applied on the composite-porcelain interface. For the tests, the specimens were placed in the matrix, exposing only the composite portion (Figure 3 ).

The data obtained were recorded and submitted to analysis of variance (ANOVA) $(\mathrm{p}<0.05)$. Individual comparisons were made with the Tukey test $(\mathrm{p}<0.05)$.

\section{RESULTS}

The means and standard deviations for the 4 groups are reported in Table 1. By comparing the results of groups 1 and 2, one observes that the performance of mechanical retentions on the porcelain surface added little to increase the bond strength of composite with porcelain. Individual comparisons performed by the Tukey test showed statistically significant differences when using conditioning with either phosphoric (group 3) or hydrofluoric acid (group 4), associated to silane agent and adhesive in the comparison to the control group (use of adhesive only) and to group 2 (mechanical retention). However, the differences be- tween the types of acids were not significant, nor were the differences between groups 1 and 2 statistically significant.

\section{DISCUSSION}

The clinical success of porcelain repair systems is almost entirely dependent on the integrity of the bond between porcelain and composite resin. The bond is achieved either by chemical or mechanical methods. Etching procedures have been used to facilitate bonding between porcelain and resin, creating a porous surface on the porcelain that leads to a retentive bond (4).

The combination of sandblasting with acids on porcelain silanization has provided the best results. When failure involves only the porcelain, the acidconditioning is effective in increasing micromechanical retention (9); but, it was observed that silane priming considerably improved bond strength to the porcelain of the composite material (17).

Hydrofluoric acid is not necessary to obtain resistant adhesion between composite and porcelain if the silane agent, which reacts with $\mathrm{OH}$ groups on the porcelain surface, is used. Silane agents appear to be the essential components for a porcelain repair procedure, by modifying its surface structure, rendering it more reactive with the composite, enabling chemical adhesion in both inorganic/porcelain and organic/composite surfaces. Theoretically, the silane bond should provide a stable repair of the fractured porcelain (18). Lacy et al. (12) observed that when silane was not applied the composite bond strength to porcelain was relatively weak, regardless of the type of surface treatment, with the failure occurring at the interface. The

Table 1. Shear resistance (in MPa) of the 4 analyzed groups.

\begin{tabular}{lrl}
\hline & Mean \pm SD & Range \\
\hline Group 1 & $4.71 \pm 1.06$ & $3.60-6.97$ \\
Group 2 & $4.81 \pm 0.61$ & $4.23-6.17$ \\
Group 3 & $11.76 \pm 1.45$ & $9.95-14.02$ \\
Group 4 & $11.07 \pm 1.83$ & $8.46-14.12$ \\
\hline
\end{tabular}

Porcelain surface treatment of group 1: no treatment; group 2: mechanical retentions performed with diamond burs; group 3: etching with phosphoric acid + silane; group 4: etching with hydrofluoric acid + silane. 
values were higher with silane application after etching. Thus, the findings suggests that bonding to porcelain is mostly chemical and not mechanical (19). The results of the present study cooborate this. Leibrock et al. (20) did not observe statistically significant differences in bond strength following thermocycling and mechanical overloading among the systems which used phosphoric or hydrofluoric acid. Owing to its chemically aggressive nature, hydrofluoric acid should be avoided and substituted by phosphoric acid, which, although aggressive, is not as noxious to tissues but produces the same effects if associated with the silane agent.

It is not possible to state whether the lower values found in this study are compatible with the clinical success of a composite repair, but quite probably, the application of silane is capable of contributing to the longevity of this sort of procedure.

\section{RESUMO}

Este estudo avaliou a resistência ao cisalhamento da união porcelana/resina, usando 40 corpos-de-prova cilíndricos de metal + porcelana + resina composta quer foram divididos em 4 grupos, de acordo com o tratamento superficial da porcelana: 1) sem tratamento, 2) retenções mecânicas feitas com ponta diamantada, 3) ataque ácido com ácido fosfórico + silano, 4) ataque ácido com ácido fluorídrico + silano. Após uma semana de armazenamento em água destilada à temperatura ambiente, os espécimes foram submetidos à carga de cisalhamento e os dados analisados estatisticamente (ANOVA). As médias dos grupos foram em MPa: 4.71 (grupo 1); 4.81 (grupo 2); 11.76 (grupo 3) e 11.07 (grupo 4). Não houve diferenças estatisticamente significantes entre os grupos 1 e 2 e entre os grupos 3 e 4 .

\section{REFERENCES}

1. Zhukovsky L, Godder B, Settembrini L, Scherer W. Repairing porcelain restorations intraorally: techniques and materials. Comp Cont Educ Dent 1996;17:18-28.

2. Pameijer CH, Louw NP, Fischer D. Repairing fractured porcelain: how surface preparation affects shear force resistance. J Am Dent Assoc 1996;127:203-209.
3. Chung KH, Hwang YC. Bonding strengths of porcelain repair systems with various surface treatments. J Prosthet Dent 1997;78:267-274.

4. Kelsey WP, Latta MA, Stanislav CM, Shaddy RS. Comparison of composite resin-to-porcelain bond strength with three adhesives. Gen Dent 2000;48:418-421.

5. Özcan M, Niedermeier W. Clinical study on the reasons for and location of failures of metal-ceramic restorations and survival of repairs. Int J Prosth 2002;15:299-302.

6. Noel LG, Michell WC. Porcelain veneer repair of prostheses. Gen Dent 1997;45:182-185.

7. Matsumura H, Atsuta M. Repair of an eight-unit fixed partial denture with a resin-bonded overcasting: a clinical report. J Prosthet Dent 1996;75:594-596.

8. Denehy G, Bouschlicher M, Vargas M. Intraoral repair of cosmetic restorations. Dent Clin N Am 1998;42:719-937.

9. Latta MA, Barkmeier WW. Approaches for intraoral repair of ceramic restorations. Comp Cont Educ Dent 2000;21:635-644.

10. Margeas RC. Salvaging a porcelain-fused-to-metal bridge with intraoral ceramic repair. Comp Cont Educ Dent 2002;23:952956.

11. Kato H, Matsumura H, Ide T, Atsuta M. Improved bonding of adhesive resin to sintered porcelain with the combination of acid etching and a two liquid silane conditioner. J Oral Rehabil 2001;28:102-108.

12. Lacy AM, La Luz J, Watanabe LG, Dellinges M. Effect of porcelain surface treatment on the bond to composite. J Prosthet Dent 1988;60:288-291.

13. Wolf DM, Powers JM, O'Keefe KL. Bond strength of composite to etched and sandblasted porcelain. Am J Dent 1993;6:155-158.

14. Kupiec KA, Wuertz KM, Barkmeier WW, Wilweding TM. Evaluation of porcelain surface treatment and agents for composite porcelain repair. J Prosthet Dent 1996;76:119-124.

15. Newburg N, Pameijer CH. Composite resin bonded to porcelain with silane solution. J Am Dent Assoc 1978;96:288-291.

16. Swift EJ, Cloe BC, Boyer DB. Effect of a silane coupling agent on composite repair strengths. Am J Dent 1994;7:200-202.

17. Chen JH, Matsumura H, Atsuta M. Effect of etchant, etching period, and silane priming on bond strength to porcelain of composite resin. Oper Dent 1998;23:250-257.

18. Shaverdi S, Canay S, Sahin E, Bilge A. Effects of different surface treatment methods on the bond strength of composite resin to porcelain. J Oral Rehabil 1998;25:699-705.

19. Berry T, Barghi N, Chung K. Effect of water storage on the silanization in porcelain repair strength. J Oral Rehabil 1999;26:459-463.

20. Leibrock A, Degenhart M, Behr M, Rosentritt M, Handel G. In vitro study of the effect of thermo- and load-cycling on the bond strength of porcelain repair systems. J Oral Rehabil 1999;26:130137. 